\title{
Human Resources Oriented: Kerangka Strategis Pengembangan MAN Insan Cendekia Kendari
}

\section{Hartin}

Dinas Pendidikan dan Kebudayaan Kota Kendari email: hartinharis82@gmail.com

\begin{abstract}
Abstrak
Artikel ini bertujuan memberikan gambaran tentang arah pengembangan MAN Insan Cendekia yang fokus pada pembentukan Sumber Daya Manusia berkualitas tinggi. Aspek-aspek yang didalami adalah proses penyiapan calon pemimpin masa depan, pengembangan minat dan bakat peserta didik, kompetensi pendidik dan tenaga kependidikan, dan tata kelola madrasah. Penelitian kualitatif digunakan untuk menjawab dimensi-dimensi kajian di atas, melalui proses wawancara, pengamatan, dan kajian dokumen. Data dianalisis melalui tahap reduksi, penyajian, dan penarikan kesimpulan. Hasil penelitian menunjukkan bahwa proses penyiapan calon pemimpin merupakan bagian penting dalam sistem pendidikan dan pembelajaran di MAN Insan Cendekia Kendari, yang tertuang dalam kegiatankegiatan yang merangsang kepeloporan dan membangun kemandirian, baik secara kurikuler maupun ekstrakurikuler. Karenanya, pengembangan minat dan bakat siswa menjadi keharusan, sebagai wahana latihan kesiapan kepemimpinan. Kesiapan tenaga pendidik diwujudkan interaksi pembelajaran di kelas yang relevan dengan kebutuhan siswa, serta kemampuan dalam mendampingi kegiatankegiatan di luar kelas. Demikian pula tenaga kependidikan, secara sinergis menjadi penopang kegiatan-kegiatan pembelajaran. Iklim MAN Insan Cendekia tersebut dapat terwujud karena tata kelola organisasi yang baik.
\end{abstract}

\section{Kata Kunci: Sumber Daya Manusia, Strategi, Tata Kelola Madrasah}




\title{
Human Resource Oriented: A Development Strategic Frame of MAN Insan Cendekia of Kendari
}

\author{
Hartin \\ Dinas Pendidikan dan Kebudayaan Kota Kendari \\ email: hartinharis82@gmail.com
}

\begin{abstract}
This article aims to provide an overview of the direction of the development of MAN IC that focuses on the formation of high quality Human Resources. The aspects explored are the process of preparing future leaders, the development of students' interests and talents, the competence of educators and education personnel, and governance of madrasas. Qualitative research is used to answer the dimensions of the study above, through a process of interviews, observations, and document review. Data were analyzed through the stages of reduction, presentation, and drawing conclusions. The results showed that the process of preparing prospective leaders is an important part of the education and learning system at MAN IC Kendari, which is contained in activities that stimulate leadership and build independence, both curricularly and extracurricularly. Therefore, the development of students' interests and talents is a must, as a vehicle for leadership readiness training. Teachers' readiness is realized by learning interactions in the classroom that are relevant to the needs of students, as well as the ability to assist activities outside the classroom. Likewise educational staff, synergistically supporting the learning activities. MAN IC climate can be realized because of good organizational governance.
\end{abstract}

Keywords: Human Resources, Strategies, Madrasa Governance 


\section{Pendahuluan}

Madrasah Aliyah Negeri Insan Cendekia atau populer dengan nama MAN IC, merupakan sebuah upaya mendudukkan sekolah agama berdiri sejajar dengan sekolah umum. Para cendekiawan muslim menyadari bahwa persekolahan yang hanya didominasi oleh ilmu-ilmu umum terasa timpang, karenanya mesti berjalan seiring dengan ilmu agama. Kehadiran MAN IC juga dapat dilihat sebagai proses mengembalikan tradisi keilmuan Islam di masa jayanya, seperti di Baghdad dan Spanyol, dimana kemajuan ilmu pengetahuan dan teknologi didasari oleh semangat keagamaan.

Tantangan kekinian yang semakin kompleks, kebangsaan maupun keumatan, pergaulan antar bangsa, menyebabkan MAN IC menyiapkan diri sebagai wahana penyiapan calon pemimpin yang memiliki kualitas paripurna ${ }^{1}$. Hal ini tergambar secara jelas pada rumusan visi dan misi MAN IC, yang menunjukkan orientasi kuat pada penguatan sumber daya manusia. Dalam perspektif perencanaan strategis, hal ini menunjukkan konsistensi MAN IC dalam menjaga relevansi dengan kondisi lingkungan ${ }^{2}$. Di samping itu, menegaskan komitmen terhadap mutu ${ }^{3}$.

Semangat untuk menghasilkan SDM berkualitas paripurna tersebut, secara perlahan dipancarkan ke berbagai penjuru negeri ${ }^{4}$. Salah satunya adalah pendirian MAN IC di Kendari pada 2017. Kehadiran sekolah ini menjadi kutub magnet baru dalam dinamika persekolahan di Sulawesi Tenggara. Citra baik yang telah terbangun sejak awal, menyebabkan sekolah ini menjadi salah satu tujuan utama para lulusan SMP sederajat.

Perkembangan MAN IC cukup menarik berbagai kalangan untuk melakukan kajian dari berbagai sudut pandang, diantaranya

1 Sukarno, M. (2017). Mengembangkan Madrasah Aliyah Negeri Insan Cendikia Untuk Menjawab Tantangan Modernisasi, Demokratisasi dan Globalisasi (Developing Insan Cendikia High School To Address Modernisation, Democracy, And Globalisation Challenges). Jurnal Kependudukan Indonesia, 9(2), 117-134.

2 Syahrul, S. (2017). Perencanaan Strategis dan Praktiknya di Perguruan Tinggi. Shautut Tarbiyah, 23(1), 142-159.

3 Syahrul, S. (2013). Penelitian sebagai Instrumen Perbaikan Kualitas Kinerja Organisasi Pendidikan secara Berkelanjutan (Continuous Improvement). AlTa'dib, 6(1), 150-163.

4 Baiturrahman, B. (2019). Analisis Kebijakan Kementerian Agama Tentang Pengembangan Madrasah (Kasus MAN Insan Cendekia) (Doctoral dissertation, Universitas Muhammadiyah Malang). 
penerapan supervisi manajerial ${ }^{5}$, supervisi keuangan ${ }^{6}$, manajemen keuangan $^{7}$, supervisi akademik $^{8}$, literasi informasi online ${ }^{9}$, kepuasan peserta didik ${ }^{10}$, hingga sistem boarding school $^{11}$.

Berbeda kajian-kajian tentang MAN IC di atas, artikel ini melakukan pendalaman terhadap orientasi sumber daya manusia dalam pengembangan MAN IC Kendari. Perspektif yang digunakan dalam kajian ini manajemen strategis.

\section{Metode}

Bahan artikel ini berasal dari hasil penelitian kualitatif dengan metode deskriptif di MAN Insan Cendekia Kendari. Pendekatan kualitatif-deskriptif merupakan upaya memahami latar suatu situasi sosial, dimana terjadi interaksi antara tiga aspek: place, actor, dan activity $^{12}$. Teknik yang digunakan dalam berinteraksi dengan situasi sosial adalah wawancara mendalam, pengamatan terlibat, dan telaah dokumen. Untuk mendapatkan informasi yang luas dan mendalam dibutuhkan informan kunci, sebagai pembuka akses pada berbagai informasi yang dibutuhkan. Data dianalisis dengan menggunakan model dari Miles yang meliputi: pengumpulan data, reduksi data,

${ }^{5}$ Muspawi, M. (2018). Implementasi Supervisi Manajerial pada MAN Insan Cendekia Provinsi Jambi. An-Nahdhah STAI Ma'arif Jambi, 12(1), 56-70.

${ }^{6}$ Muspawi, M. (2018). Implementasi Supervisi Keuangan pada MAN Insan Cendekia Provinsi Jambi. Jurnal Sains Sosio Humaniora LPPM Universitas Jambi, 2(1), 16-24.

${ }^{7}$ Arianti, D. (2014). Penerapan Manajemen Keuangan Pendidikan di MAN Insan Cendekia Serpong.

${ }^{8}$ Muspawi, M. (2017). Implementasi Supervisi Akademik pada MAN Insan Cendekia Provinsi Jambi. Ta'dib: Jurnal Pendidikan Islam, 6(2), 291-298.

${ }^{9}$ Deliasari, A., \& Kurnianingsih, I. (2017). Analisis Kebutuhan Topik Pembelajaran Literasi Informasi Online Pada Perpustakaan Sekolah MAN Insan Cendekia. Edulib, 7(2).

${ }^{10}$ Elfachmi, A. K., \& Amida, F. (2016). Analisis Pengaruh Kualitas Pelayanan Dan Sarana Prasarana Terhadap Kepuasan Peserta Didik Studi Pada Man Insan Cendekia Serpong Tangerang Selatan. EDUKA Jurnal Pendidikan, Hukum dan Bisnis, 1(1), 12-32.

${ }^{11}$ Aisyah, S. (2016). Boarding School Sebagai Penunjang Keberhasilan Pendidikan Nilai Di Man Insan Cendekia Serpong (Bachelor's thesis). Alfabeta (2005)

${ }^{12}$ Lihat Sugiyono, Prof. "Memahami Penelitian Kualitatif." Bandung: 
penyajian data, dan penarikan kesimpulan ${ }^{13}$. Keabsahan data diuji melalui proses trianggulasi, member check, perpanjangan pengamatan dan peningkatan ketekunan ${ }^{14}$.

\section{Hasil dan Pembahasan}

\section{A. Menyemai Pemimpin Masa Depan: Gagasan Dasar MAN Insan Cendekia}

Pembentukan MAN IC berawal dari kebutuhan sumber daya manusia yang memiliki kualifikasi tinggi akan ilmu pengetahuan maupun teknologi dan sejalan dengan keimanan maupun ketaqwaan. B.J. Habibie menginisiasi lewat BPPT (Badan Pengkajian dan Penerapan Teknologi) membentuk STEP (Sience and Technology Equity Program). Tujuan STEP adalah penyetaraan program ilmu pengetahuan dan teknologi untuk sekolah di lingkungan pesantren ${ }^{15}$.

Tahun 1996, STEP melekatkan nama SMU Insan Cendekia (IC) sebagai nama lembaga pendidikan. STEP memilih lokasi di Serpong (Tangerang) dan Gorontalo. Rancangan model pendidikan STEP mengambil filosofi magnet school, dimana mampu menarik sekolah sekitarnya untuk terpicu dalam prestasi dan menyiapkan calon pemimpin masa depan bangsa. Tahun 2000, BPPT melimpahkan manajerial SMU IC ke Departemen Agama dan mengubahnya menjadi MAN (Madrasah Aliyah Negeri) Insan Cendikia ${ }^{6}$. Untuk memperluas semangat Insan Cendekia, pemerintah melalui Kementerian Agama mendirikan 17 MAN IC di seluruh Indonesia termasuk MAN IC Kendari yang terletak di Kel. Baruga Kec. Baruga (Belakang Brimob Sultra) yang dibangun di atas lahan hibah dari Pemerintah kota Kendari seluas $10 \mathrm{Ha}^{17}$. (terjemahan).

${ }^{13}$ Miles, M. B., \& Huberman, A. M. (2007). Qualitative Data Analysis (2002).

${ }^{14}$ Lexy, J. Moleong. "Metode penelitian kualitatif." Bandung: Rosda Karya

15 www.ickendari.sch.id. (2018, Agustus 17). Dipetik Januari 11, 2020, dari www.ickendari.sch.id: https://www.ickendari.sch.id/sejarah-singkat/

${ }^{16}$ Republika.co.id. (2014, Januari 11). MAN Insan Cendekia: Madrasah dengan Segudang Prestasi. Dipetik Januari 12, 2020, dari Repbulika.co.id: https://www.republika.co.id/berita/pendidikan/eduaction/14/01/13/mz7ipd-maninsan-cendekia-madrasah-dengan-segudang-prestasi.

17 www.ickendari.sch.id. (2018, Agustus 17). Dipetik Januari 11, 2020, dari www.ickendari.sch.id: https://www.ickendari.sch.id/sejarah-singkat/ 
MAN IC Kendari, dalam proses belajar mengajar nantinya mengikuti model MAN IC yang telah menghasilkan siswa-siswa terbaik yang telah berprestasi baik di tingkat Nasional maupun di tingkat Internasional dimana setiap tahun, 97\% alumni MAN IC Serpong diterima di PTN favorit, hanya 3\% di PT swasta Favorit ${ }^{18}$. Total sebaran lulusan MAN IC Serpong dari tahun 1998 hingga 2013 yang melanjutkan dan diterima di PTN cukup tinggi, yaitu di Institut Teknologi Bandung (33\%), Universitas Gadjah Mada (20\%), Universitas Indonesia (16\%), Unpad (8\%), PTN lainnya (18\%), dan PTS (5\%). Alumni di perguruan tinggi luar negeri antara lain Jepang (42\%), Jerman (14\%), Malaysia (14\%), Singapura (8\%), Amerika (7\%), Mesir (7\%), Korea (5\%), Australia (2\%), dan Rusia $(1 \%)^{19}$. Disamping itu MAN IC Serpong berhasil meraih beberapa penghargaan Internasional dalam berbagai Kegiatan Olimpiade (Fisika, Biologi, Matematika, Geografi) di berbagai Negara (Kanada, Korea Selatan, Taiwan, Italia, Australia, Rusia, Polandia, Denmark).

Sejak tahun 2000, MAN Insan Cendekia, baik yang berada di Gorontalo maupun di Serpong, dilimpahkan pengelolaannya oleh BPPT kepada pihak Kementerian Agama. Selanjutnya, nama SMU Insan Cendekia bertransformasi menjadi MAN Insan Cendekia. Tanpa mengurangi dan mengubah sistem pengajaran secara keseluruhan yang telah berjalan selama ini. Saat ini ada 3 MAN IC yang telah eksis dan bertabur prestasi yaitu MAN IC Serpong, Gor5ontalo dan Jambi. Keberadaan dan prestasi dari MAN IC tersebut perlu ditularkan di 20 lokasi MAN IC baru di seluruh Indonesia, salah satunya berada di Kota Kendari.

Dari 20 lokasi yang sedang dibangun ada 5 MAN IC yang siap menerima siswa baru pada tahun 2015, yaitu MAN IC Siak (Riau), MAN IC Ogan Komering Ilir (Sumsel), MAN IC Paser

\footnotetext{
${ }^{18}$ Hukum.Com, B. (2013, Agustus 12). Berita Hukum.Com. Dipetik Januari 11, 2020, dari Berita Hukum.Com: http://m.beritahukum.com/detail_berita.php?judul=97\%\%20Lulusan\%20MAN\%20I C\%20Serpong\%20Tahun\%202013\%20Masuk\%20PTN\%20Favorit

19 Timur, K. K. (2013, Agustus 15). Kelompok Kerja Pengawas Jakarta Timur. Dipetik Januari 12, 2020, dari Kelompok Kerja Pengawas Jakarta Timur: https://pokjawasjaktim.wordpress.com/2013/08/15/97-lulusan-man-ic-serpongtahun-2013-masuk-ptn-favorit/
} 
(Kalimantan Timur), MAN IC Pekalongan (Jawa Tengah), MAN IC Aceh Timur (Aceh) dan MAN IC Bangka Tengah ${ }^{20}$.

\section{B. Strategi Pengembangan MAN Insan Cendekia Kendari}

Nama Madrasah MAN INSAN CENDEKIA kota Kendari yang berstatus Negeri dan waktu belajar dilakukan dari pagi sampai siang dengan jurusan/program MIPA dan IPS dengan kategori madrasah Madrasah akademik berbasis pesantren, luas tanah 7.000 M3, mempunyai ciri khas dalam penggunaan bahasa Arab dan bahas Inggris. MAN Insan Cendekia berlokasi di Jalan Insan Cendekia Nomor 16 desa/kelurahan Baruga kecamatan Baruga kabupaten/kota Kendari provinsi Sulawesi Tenggara, kode pos 93116, kategori Geografis wilayah dataram tinggi. Alamat website madrasah dapat dilihat www.ickendari.sch.id, dan alamat email madrasah manic.kotakendari@gmail.com No. SK Pendirian 744 Tahun 2017, tanggal SK Pendarian 02/10/2017, status dalam KKM adalah anggota KKM, status komite madrasah sudah terbentuk dengan daya tamping 192 siswa, nama lengkap kepala sekolah Dr. Abdul Basit, S.Ag.,MM. Jenis kelamin laki-laki status kepegawaian PNS, NIP 197510052005011005, Pendidikan terakhir S3, sudah sertifikasi.

\section{Visi Madrasah}

"terwujudnya sumber daya manusia yang berkualitas tinggi dalam keimanan dan ketakwaan, menguasai ilmu pengetahuan dan teknologi, dan mampu mengaktualisasikan dalam masyarakat.

\section{Misi Madrasah}

1. Menyiapkan calon pemimpin masa depan yang menguasai ilmu pengetahuan dan teknologi, mempunyai daya juang tinggi, mampu berkomunikasi dalam bahasa international, inovatif dan mempunyai landasan iman dan takwa yang kuat.

2. Menumbuh-kembangkan minat, bakat, dan potensi peserta didik untuk meraih prestasi pada tingkat nasional sampai internasional.

3. Meningkatkan pengetahuan dan kemampuan professional pendidik dan tenaga kependidikan sesuai dengan perkembangan dunia pendidikan

20 www.ickendari.sch.id. (2018, Agustus 17). Dipetik Januari 11, 2020, dari www.ickendari.sch.id: https://www.ickendari.sch.id/sejarah-singkat/ 
4. Menjadikan MAN Insan Cendikia kota kendari sebagai lembaga pendidikan yang bertata kelola dan mandiri yang berwawasan lingkungan.

5. Menjadikan MAN Insan Cendikia kota kendari sebagai madrasah model dalam pengembangan pengajaran IPTEK dan IMTAK, serta berwawasan lingkungan bagi lembaga pendidikan lainnya.

MAN IC mulai dipergunakan pada Juni di tahun 2016, dengan mengedepankan Sains tanpa mengabaikan nilai-nilai agama oleh karena itu muatan kurikulum di MAN IC 100\% akademik dan 100\% agama. Untuk melaksanakan/mewujudkan hal itu maka MAN IC membuat boarding school sebagai tempat tinggal siswa dan pembinaan keagamaan siswa di MAN IC Kendari. Adapun proses belajar mengajar MAN IC mempunya waktu yang cukup padat dan dapat diklasifikasikan menjadi 4 bagian:

1. Pembelajaran formal (kelas) mulai jam 7-3 sore. Pembelajaran ini merupakan pembelajaran dikelas seperti secara umum lainnya atau full day school yang merupakan implemetasi dari kurikulum 2013

2. Pembelajaran ekstrakurikuler/pendalaman materi terkait ekstrakulikuler yang diterapkan di MAN IC seperti bimbingan olimpiade sains, bimbingan KTI (karya tulis ilmiah) dan bimbingan kegiatan lainnya. Waktunya dari setelah Ashar sampai jam setengah 6. Waktu yang digunakan adalah ba'da ashar sampai setengah enam dan kontinui.

3. Pembelajaran boarding dari ba'da maghrib sampai Isya adapun kegiatannya adalah tahsin, tahfidz, bimbingan imam masjid, bimbingan khatib kemudian ada kajian tematik dan kitab klasik/kitab kuning. Pembelajaran ini dilakukan agar siswa berprestasi dalam bidang agama terlebih sebagai mubaligh.

4. Pembelajaran mandiri dari jam 9 sampai jam 10 maksimal, seperti mengerjakan tugas-tugas dan persiapan pada siswa yang akan mengikuti lomba, dan pembelajaran bahasa setelah subuh. Namun semua kegiatan ini tidak terlepas dari para pembimbing mereka yang mendampingi.

MAN IC Kendari mempunyai program untuk menulis mushaf setiap orang 30 juz dan ini adalah kegiatan wajib sehingga siswa MAN IC tidak bisa lulus jika tibak menulis mushaf dan kegiatan ini dilakukan di waktu-waktu luang mulai siswa masuk di MAN IC sampai tamat dan harus mempunyai mushaf yang ditulis oleh setiap siswa adapun pembimbingannya yaitu siswa langsung melihat al- 
qur'an dan akan dikoreksi oleh pembimbingnya, adapun penekanannya disini adalah literasi agar siswa terbiasa untuk menulis al-qur'an karena sekarang orang bisa menjadi hafidz tapi belum tentu bisa menulis mushaf dan siswa juga diwajibkan untuk menghafal hadis arba'in sebagai standar asramah dan harus mempunyai hafalan al-qur'an 3 juz namun ada yang sampai 5,10 dan 20 juz dan untuk sementara baru sekitar 20 juz yang dihafal dan harus mempunyai 1 penelitian selama selama sekolah di MAN IC.

MAN IC melakukan sistem boarding dan menjunjung tinggi sains tanpa menafikkan nilai agama kemudian penambahan jam, strategi mengajar dan guru model mengajar sehingga prestasi siswa sudah sampai mengikuti nasional dan interational MAN IC baru dua angkatan sehingga belum ada lulusan. Adapun dalam aspek IT siswa hampir semua siswa telah mempunya laptop untuk mencari informasi dan anak-anak ditekankan untuk berkretaiv, mandiri dan berinovasi. Karena zamn modern ini memacu siswa agar tidak gagap teknologi dan mereka untuk belajar mandiri.

Mulai januari sudah harus meneliti dan akhir tahun sudah harus selesai dan karena pada saat libur semester siswa disuruh untuk meneliti dikampung dan ketika mereka kembali makan sudah harus siap proposal dan dikahir tahun harus siap layaknya seperti mahasiswa yaitu skripsi. Untuk membimbing KTI Maka satu pembimbing mengajar 10-15 siswa dan juga punya dokter KIR.

Guru berjumlah 25 orang dan ada yang sudah tinggal didalam karena ada rumah dinas guru, dan setelah ada gedung dinas ini maka guru wajib tinggal di dalam. Siswa 137 orang, dan siswa yang masuk di MAN IC dibatasi setiap angkatan meneria 96 siswa karena MAN IC Langsung dikelola oleh kementrian agama dibawah dirjen pendis jadi hanya dikasih kuota dengan formasi 3 kelas dan satu angkatan maksimal 24 orang nda bisa lebih, dan uniknya MAN IC tidak bisa menerima siswa pindahan selama proses sekolah berlangsung kecuali sesame MAN IC. Dan regular tidak bisa mutasi ke MAN IC.

Proses pendaftaran sama dengan model seleksi nasionl masuk perguruan tinggi dengan pendaftaran online seindonesi sistemnya nasional, kemudia tesnya juga ada psikologi dan yang bisa mendaftar hanya prestasi 10 besar dan ada lagi seleksi akademik dan psikologi, dan dari sekolah terakredutasi, dan ini baru mendaftar belum seleksi. Dan untuk biaya pendaftaran tidak ada, spp juga tidak ada, uang asramah yang ada hanya hanya biaya makan perbulan 1 juta, nutk 
beasiswa ada juga bagi yang tidak mampu yang penting dia cerdas dan mampu maka dibebaskan biaya.

MAN IC dulunya adalah MAN IC Serpong berdiri duluan tahun 1997 bulan 2 dan kita MAN IC Kendari mengadopsi semua sistem manajemen yang ada di MAN IC Serpong dan gorontalo yang sudah dulu berjalan, prestasi MAN IC sudah banyak mengikuti lombalomba nasional maupun internasional dan perkembangannya cukup pesat karena berpascu sebagai tantangan MAN IC tersendiri. Untuk pegawai/guru MAN IC maka diseleksi oleh pusat dan serentak seindonesia dan tidak semua PNS, karena tidak melihat PNS maupun tidak namun dibuka untuk umum dan barang siapa yang mampu maka semua bisa mengajar di MAN IC yang jelas lolos seleksi, jadi seleksinya adalah tes akademik dan tes micro teaching, yang diawali dengan seleksi berkas.

Kondisi sarana dan prasarana di MAN IC Kendari belum tersedia sesuai dengan standar kebutuhan baru ada asramah putra, rumah dinas, asramah putri masih sementara dikerja yang seharusnya harus sudah ada lab terpadu, masjid, sarana olahraga, kegiatan olahraga siswa, poliklinik, gedung administrasi, karena standar MAN IC sangat tinggi makanya lahan untuk MAN IC ini ada 10 hektar karena kebutuhan sarananya yang sangat banyak dengan situasi yang sangat bening karena lokasinya berada di hutan yang jauh dari rumah masyarakat, kemudian disana juga banyak lalat pada rungan-ruangan MAN IC seperti TU dan ruangan belajar, gedung administrasi belum ada sehingga proses pembangungan bertahan dan diharapkan 20192020 sudah lengkap sarana dan prasaranya.

Kurikulum yang digunakan adalah kurikulum 2013 sesuai dengan ketentuan umum, adapun manajemen berbasis sekolah diterapkan guna menjalin kerjasama dengan masyarakat dan orang tua siswa, kemudian peran komite sagat besar hamoir semua kegiatan diurusi oleh komite dan berkerjasama dengan berbagai perusahaan dan sudah dua MOU, karena sekolah ungguluan tidak bisa meninggalkan peran masyarakat atau stakeholder, mereka harus melakukan kerjasama dan salah satunya bersama orang tua, beberapa orang tua membantu untuk membuat sumur bor, namun bantuan itu butuh balasan dengan presatasi siswanya sehingga masyarakat dapat percaya, dan memang sekolah baru sangat banyak tantangan, namun bukan menjadi halangan, sehngga perlu lompatan-lompatan akademik baru kelas 10 dan 11 sudah mulai bersaing dan di kendari MAN IC 
sudah sangat diperhitungkan sudah tidak kalah saing dengan SMA, SMK lainnya.

Adapun kendala-kendala di MAN IC adalah dari sisi sarana, guru masih beberapa bidang studi belum ada guru tetapnya, kemudian guru asrama ada tiga idealnya empat, dari sisi kelembagaan unit-unit masih keruang, kewirausahaan juga belum berjalan.

Adapun kendala dalam pembuatan karya tulis ilmiah masih belum terlalu tau karena baru memulai meneliti namun akan terus dibimbing dan merupakan kegiatan ekstrakurikuler, adapun jurusannya itu ada IPA dan IPS, dari aspek manajemen yaitu sudah mulai ada tata kelola wakil madrasah ada lima yaitu salah satu pembedannya ada wakil asramh pada struktur orgaisasi kepalaa sekolah sebagai top manajer kemudia ada waka dan baru satu kepala sekolah yang sering disebut asabiqul awalh orang-orang awalah yang mengembangkan MAN IC dan guru juga dikontrak jadi klw sudah tidak mampu maka dikeluarkan walaupun PNS dan itu setiao tahun evaluasi dan sudah ada perjanjian menajdi guru di MAN Insan cendikia yang langsung diataur oleh kemenag.

Karena MAN IC bukan local tapi internasional dan nasional karena targetnya/ misinya adalah harus jadi pemimpin masa depat dimanapun, jadi sangat diasah diekstrakurikuler dan harus ada budaya yang berbeda di MAN IC Kendari menjadikan sekolah yang berbudaya akademik yang harus ditanamkan pada siswa dan harus mempunyai komitmen yang tinggi oleh karena itu harus dikontrak karena apabila tidak mampu maka akan di geser dan dikeluarkan dari MAN IC.

Sistem seleksi calon peserta didik MAN Insan Cendekia dilakukan di tingkat nasional dengan cara on line yang dilakukan oleh pemerintah pusat dengan quota tertentu bagi putra daerah.

Kriteria khusus bagi calon peserta didik baru yang akan masuk sebagai berikut:

1. Memiliki rata-rata nilai akademik 5 semester terakhir SMP/MTs di atas 8 ,

2. Memiliki kemampuan mengoperasionalkan komputer,

3. Memiliki kemampuan dasar Bahasa Inggris,

4. Memiliki kecerdasan di atas rata-rata,

5. Memiliki pemikiran, sikap dan perilaku yang kritis dan inovatif. 


\section{Biaya Pendidikan}

Berdasarkan Keputusan Direktur Jenderal Pendidikan Islam Kementerian Agama Nomor 3192 Tahun 2013 Tentang Pedoman Penyelenggaraan Madrasah Aliyah Negeri Insan Cendekia, dalam rangka memberi layanan pendidikan pada MAN Insan Cendekia yang berkeadilan, maka terhitung mulai tahun pelajaran 2015/2016 peserta didik baru MAN Insan Cendekia dikenakan biaya personal berupa biaya asrama, makan, dan pakaian seragam yang tidak dianggarkan dalam DIPA MAN Insan Cendekia (besaran biayanya akan ditentukan kemudian) kecuali bagi peserta didik yang berasal dari keluarga kurang mampu yang dibuktikan dengan menyertakan Kartu Keluarga Sejahtera (KKS) atau kartu Program Keluarga Harapan (PKH) atau Kartu Indonesia Pintar (KIP).

Fasilitas MAN IC Kendari terdiri dari:

1. Ruangan Kelas dan Asrama ber-AC

2. Asrama berstandar Apartemen

3. Jumlah siswa perkelas 24 siswa

4. Guru MAN IC hasil seleksi Nasional

5. Pendampingan guru 24 jam

6. Bahasa pengantar menggunakan 3 Bahasa (Indonesia, Arab dan Inggris)

7. Rutin mengikuti kegiatan lomba sains berstandar Olimpiade

8. Ruang kelas dan Lab dengan fasilitas Multimedia

9. Internet dengan fasilitas Wifi

10. Lantai gedung berbahan granit

11. Fasilitas Olahraga

12. Bangunan tanpa unsur kayu, menggunakan unsur baja

13. Lab. Fisika, Lab. Kimia, Lab. Biologi, Lab. Komputer P

14. Penerangan dan air bersih terjami

Madrasah Aliyah Negeri Insan Cendekia (MAN IC) Kota Kendari menjadi salah satu sekolah yang diperebutkan oleh siswa yang berasal dari seluruh pelosok Sultra, pasalnya ada ratusan siswa Sekolah Menengah Pertama (SMP) yang ingin masuk di sekolah ini. Hal itu dibenarkan oleh Kepala Sekolah (Kepsek) MAN Insan Cendekia Kendari, Dr. Abdul Basit S.Ag., MM. Ia mengatakan bahwa ada ratusan calon siswa yang mengikuti sistem Seleksi Nasional Peserta Didik (SNPDB). "Sebanyak 282 calon siswa mencoba peruntungan dengan mengikuti Sistem Seleksi Nasional Peserta Didik 
Baru MAN IC Kendari, sementara kuota yang dibutuhkan hanya 96 siswa saja.

Bapak Abdul Basit menuturkan, lokasi SNPDB tersebut tersebar di empat lokasi, yakni di MAN IC Kendari, Wakatobi, BauBau dan Kolaka. Ia melanjutkan, saat ini sementara menunggu pengumuman kelulusan yakni pada tanggal 18 April dan untuk awal masuk asrama yakni 14 Juli 2018. Ia berharap bahwa MAN Cendekia bisa menjadi institusi yang dapat menghasilkan insan-insan akademis berkualitas ke depannya. Untuk diketahui, saat ini pendaftar yang mengikuti SNPDB MAN IC yang ada di 32 provinsi mencapai 10.587 siswa dan tersebar di 47 lokasi tes SNPDB MAN IC se-Indonesia.

\section{Pendidik dan tenaga kependidikan}

Jumlah kepala madrasa 1, wakil kepala madrasah PNS lakilaki 1 dan perempuan 1, adapn yang non PNS 1 laki-laki dan dua perempuan, jumlah pendidik PNS 6 laki-laki dan 6 perempuan dan non PNS 5 laki-laki dan 3 perempuan, adapun jumlah tenaga kependidikan 1 PNS laki-laki dan 1 perempuan dan non PNS 8 lakilaki dan 3 perempuan.

\section{E. Pembinaan Minat dan Bakat}

Jumlah siswa laki-laki kelas 10 yaitu 38 dan perempuan 44 orang jadi jumlahnya adalah 82 untuk kelas 11 jumlah siswa laki-laki 28 dan perempuan 36 orang dan MAN IC baru sampai dua angkatan sehingga jumlah semua siswa adalah 144 orang.

TIM A dan TIM C MAN IC Kendari Berhasil memenangkan dan mendapatkan juara 1 dan 2 pada Lomba Cerdas Cermat Geography Smart Competition se-kota kendari.

\section{E. Prestasi Madrasah dan Ekstrakurikuler}

\begin{tabular}{|l|l|l|l|l|}
\hline No & \multicolumn{1}{|c|}{ Kegiatan } & \multicolumn{1}{|c|}{ Prestasi } & $\begin{array}{c}\text { Tingkat/pen } \\
\text { yelenggara }\end{array}$ & Tahun \\
\hline 1 & Lomba karnava & 5 & Kota kendari & 2016 \\
\hline 2 & Lomba drama & terbaik & provinsi & 2016 \\
\hline 3 & $\begin{array}{l}\text { Lomba pidato } \\
\text { bahasa inggris }\end{array}$ & 1 & Kota kendari & 2016 \\
\hline 4 & $\begin{array}{l}\text { Lomba pidato } \\
\text { bahasa arab }\end{array}$ & 1 & Kota kendari & 2016 \\
\hline
\end{tabular}




\begin{tabular}{|c|c|c|c|c|}
\hline 5 & $\begin{array}{ll}\text { Lomba } & \text { film } \\
\text { pendek } & \end{array}$ & 1 & Kota kendari & 2016 \\
\hline 6 & $\begin{array}{l}\text { Kompetensi sains } \\
\text { madrasah }\end{array}$ & partisipasi & partisipasi & 2016 \\
\hline 7 & $\begin{array}{ll}\text { Lomba } & \text { tenis } \\
\text { meja putra } & \end{array}$ & 2 & Kota kendar & 2016 \\
\hline 8 & $\begin{array}{ll}\text { Lomba } & \text { tenis } \\
\text { meja putri }\end{array}$ & 1 & Kota kendari & 2016 \\
\hline 9 & $\begin{array}{l}\text { Lomba cerdas } \\
\text { terampil }\end{array}$ & 1 & $\mathrm{UHO}$ & 2016 \\
\hline 10 & $\begin{array}{l}\text { Lomba } \\
\text { pertolongan } \\
\text { utama }\end{array}$ & 1 & $\mathrm{UHO}$ & 2016 \\
\hline 11 & Jambore nasional & partisipasi & Nasional & 2016 \\
\hline 12 & $\begin{array}{l}\text { Perkemahan } \\
\text { jambore nasional }\end{array}$ & partisipasi & Nasional & 2016 \\
\hline 13 & $\begin{array}{l}\text { Jambore } \\
\text { internasional } \\
\text { malaysia }\end{array}$ & partisipasi & Internasional & 2016 \\
\hline 14 & Jurnalis terbaik & terbaik & Provinsi & 2016 \\
\hline 15 & $\begin{array}{l}\text { Perkemahan } \\
\text { madrasah }\end{array}$ & partisipasi & kemenag & 2016 \\
\hline 16 & $\begin{array}{l}\text { Debat bahasa } \\
\text { inggris }\end{array}$ & partisipasi & $\begin{array}{ll}\text { MAN } & \text { IC } \\
\text { Serpong } & \end{array}$ & 2016 \\
\hline 17 & Story telling & partisipasi & $\begin{array}{ll}\text { MAN } & \text { IC } \\
\text { Serpong } & \\
\end{array}$ & 2016 \\
\hline 18 & $\begin{array}{l}\text { Lawatan sejarah } \\
\text { nasional }\end{array}$ & partisipasi & Nasional & 2016 \\
\hline 19 & $\begin{array}{l}\text { Pidato produk } \\
\text { halal }\end{array}$ & 1 & Kota kendari & 2017 \\
\hline 20 & $\begin{array}{ll}\text { Pidato } & \text { TK. } \\
\text { Provinsi } & \\
\end{array}$ & 2 & Provinsi & 2017 \\
\hline 21 & $\begin{array}{l}\text { Fotografi } \\
\text { Olimpiade } \\
\text { Biologi }\end{array}$ & 3 & $\begin{array}{l}\text { Provinsi/UH } \\
\mathrm{O}\end{array}$ & 2017 \\
\hline 22 & Tenis meja jurda & 4 & Provinsi & 2017 \\
\hline 23 & $\begin{array}{l}\text { Lomba cerdas } \\
\text { terampil putra }\end{array}$ & 1 & Kota kendari & 2017 \\
\hline
\end{tabular}




\begin{tabular}{|c|c|c|c|c|}
\hline 24 & $\begin{array}{l}\text { Lomba cerdas } \\
\text { terapil putri }\end{array}$ & 3 & Ota kendari & 2017 \\
\hline 25 & Zetizen kendari & partisipasi & Nasional & 2017 \\
\hline 26 & $\begin{array}{l}\text { Jambore asia } \\
\text { pasifik mangolia }\end{array}$ & partisipasi & international & 2017 \\
\hline 27 & $\begin{array}{l}\text { Perkemahan } \\
\text { ilmiah remaja } \\
\text { internatioal }\end{array}$ & partisipasi & LIPI & 2017 \\
\hline 28 & Tenis meja putri & 1 & Provinsi & 2017 \\
\hline 29 & Lomba presenter & 10 & Provinsi & 2017 \\
\hline 30 & $\begin{array}{l}\text { Olimpiade } \\
\text { bahasa inggris }\end{array}$ & Partisipasi & UHO & 2017 \\
\hline 31 & $\begin{array}{l}\text { Olimpiade } \\
\text { biologi }\end{array}$ & Partisipasi & UHO & 2017 \\
\hline 32 & $\begin{array}{l}\text { Olimpiade mati- } \\
\text { matika }\end{array}$ & Partisipasi & UNESA & 2017 \\
\hline 33 & $\begin{array}{l}\text { Olimpiade } \\
\text { geografi }\end{array}$ & Partisipasi & UNHAS & 2017 \\
\hline 34 & $\begin{array}{l}\text { Olimpiade } \\
\text { ekonomi }\end{array}$ & Partisipasi & $\begin{array}{l}\text { Universitas } \\
\text { Indonesia }\end{array}$ & 2017 \\
\hline 35 & $\begin{array}{l}\text { Olimpiade } \\
\text { sejarah }\end{array}$ & Partisipasi & $\begin{array}{l}\text { Politeknik } \\
\text { Jakarta }\end{array}$ & 2017 \\
\hline 36 & Olimpiade kimia & Partisipasi & $\begin{array}{l}\text { Nasional/UN } \\
\mathrm{M}\end{array}$ & 2017 \\
\hline 37 & Olimpiade fisika & Partisipasi & UHO & 2017 \\
\hline 38 & $\begin{array}{l}\text { Raimuna } \\
\text { nasional }\end{array}$ & Partisipasi & $\mathrm{UHO}$ & 2017 \\
\hline 39 & $\begin{array}{l}\text { Lomba karnaval } \\
\text { juang } 45\end{array}$ & 2 & Kota kendari & 2017 \\
\hline 40 & $\begin{array}{l}\text { Olimpiade } \\
\text { bahasa arab }\end{array}$ & Partisipasi & Nasional & 2017 \\
\hline 41 & Syahril quran & 1 & Kota kendari & 2018 \\
\hline 42 & Famil qur'an & 3 & Kabupaten & 2018 \\
\hline 43 & Syahril quran & 3 & Kabupaten & 2018 \\
\hline 44 & $\begin{array}{l}\text { Tafsir bahasa } \\
\text { inggris }\end{array}$ & 1 & Kabupaten & 2018 \\
\hline 45 & LKTI Nasional & 2 & Kabupaten & 2018 \\
\hline
\end{tabular}




\begin{tabular}{|l|l|l|l|l|}
\hline 46 & LCT Biologi & 2 & Provinsi & 2018 \\
\hline 47 & KIR & Harapan 3 & Provinsi & 2018 \\
\hline
\end{tabular}

F. Kegiatan Ekstrakuriuler yang diselenggarakan Madrasah

1. Pramuka

2. Palang merah remaja

3. Pasukan pengibar bendera

4. Karya ilmiah remaja (KIR)

5. Seni suara/vocal group

6. Robotic

7. Sepakbola/futsal

8. Jurnalistik

9. Kaligrafi

10. Olimpiade biologi

11. Olimpiade matematika

12. Olimpiade dfisika

13. Olimpiade kimia

14. Olimpiade ekonomi

15. Olimpiade geografi

G. Sarana dan prasarana MAN Insan Cendekia

\begin{tabular}{|l|l|c|}
\hline No & Jenis & Jumlah \\
\hline 1. & Ruang kelas & 15 \\
\hline 2. & Toilet guru & 2 \\
\hline 3 & Toilet siswa & 40 \\
\hline 4. & Masjid/mushola & 1 \\
\hline 5. & Asramah siswa (putra) & 1 \\
\hline 6. & Asramah siswa (putri) & 1 \\
\hline 7. & Kantin & 1 \\
\hline 8. & Kursi siswa & 148 \\
\hline 9. & Meja siswa & 148 \\
\hline 10 & Loker siswa & 42 \\
\hline 11. & Kursi guru di ruang kelas & 7 \\
\hline 12. & Meja guru di ruang kelas & 7 \\
\hline 13. & Papan tulis & 7 \\
\hline 14. & Lemari & 6 \\
\hline 15. & Bola basket & 2 \\
\hline 16. & Laptop (di luar yang ada di & 6 \\
\hline
\end{tabular}




\begin{tabular}{|l|l|c|}
\hline & lab komputer) & 3 \\
\hline 17. & $\begin{array}{l}\text { Komputer (di luar yang ada } \\
\text { di lab. Komputer) }\end{array}$ & 3 \\
\hline 18. & Printer & 1 \\
\hline 19 & Mesin fotocopy & 1 \\
\hline 20. & Mesin scanner & 7 \\
\hline 21. & LCD Proyektor & 5 \\
\hline 22. & Layar (screen) & 24 \\
\hline 23. & Meja guru dan pegawai & 24 \\
\hline 24. & Kursi guru dan pegawai & 1 \\
\hline 25. & Lemari arsip & 1 \\
\hline 26. & Kotak obat P3K & 1 \\
\hline 27. & BANKES & 4 \\
\hline 28. & Pengeras suara & 2 \\
\hline 29. & $\begin{array}{l}\text { Washtafel (tempat cuci } \\
\text { tangan }\end{array}$ & $\begin{array}{l}\text { Kendaraan operasional } \\
\text { (mobil) }\end{array}$ \\
\hline 30. & \\
\hline
\end{tabular}

\section{Kesimpulan dan Saran}

Penelitian menunjukkan bahwa proses penyiapan calon pemimpin merupakan bagian penting dalam sistem pendidikan dan pembelajaran di MAN Insan Cendekia Kendari, yang tertuang dalam kegiatan-kegiatan yang merangsang kepeloporan dan membangun kemandirian, baik secara kurikuler maupun ekstrakurikuler. Karenanya, pengembangan minat dan bakat siswa menjadi keharusan, sebagai wahana latihan kesiapan kepemimpinan. Kesiapan tenaga pendidik diwujudkan interaksi pembelajaran di kelas yang relevan dengan kebutuhan siswa, serta kemampuan dalam mendampingi kegiatan-kegiatan di luar kelas. Demikian pula tenaga kependidikan, secara sinergis menjadi penopang kegiatan-kegiatan pembelajaran. Iklim MAN Insan Cendekia tersebut dapat terwujud karena tata kelola organisasi yang baik.

Penelitian ini merekomendasikan pentingnya menegaskan bahwa penyelenggaraan sekolah mesti mengarah para penguatan sumber daya manusia. Hal ini kemudian ditindaklanjuti menjadi rumusan rencana strategis, dan terukur dalam bentuk indikator kinerja utama. 


\section{Daftar Pustaka}

Aisyah, S. (2016). Boarding School Sebagai Penunjang Keberhasilan Pendidikan Nilai Di Man Insan Cendekia Serpong (Bachelor's thesis).

Arianti, D. (2014). Penerapan Manajemen Keuangan Pendidikan di MAN Insan Cendekia Serpong.

Baiturrahman, B. (2019). Analisis Kebijakan Kementerian Agama Tentang Pengembangan Madrasah (Kasus MAN Insan Cendekia) (Doctoral dissertation, Universitas Muhammadiyah Malang).

Deliasari, A., \& Kurnianingsih, I. (2017). Analisis Kebutuhan Topik Pembelajaran Literasi Informasi Online Pada Perpustakaan Sekolah MAN Insan Cendekia. Edulib, 7(2).

Elfachmi, A. K., \& Amida, F. (2016). Analisis Pengaruh Kualitas Pelayanan Dan Sarana Prasarana Terhadap Kepuasan Peserta Didik Studi Pada Man Insan Cendekia Serpong Tangerang Selatan. EDUKA Jurnal Pendidikan, Hukum dan Bisnis, 1(1), 12-32.

Lexy, J. Moleong. "Metode penelitian kualitatif." Bandung: Rosda Karya (2002).

Miles, M. B., \& Huberman, A. M. (2007). Qualitative Data Analysis (terjemahan).

Muspawi, M. (2018). Implementasi Supervisi Manajerial pada MAN Insan Cendekia Provinsi Jambi. An-Nahdhah STAI Ma'arif Jambi, 12(1), 56-70.

Muspawi, M. (2018). Implementasi Supervisi Keuangan pada MAN Insan Cendekia Provinsi Jambi. Jurnal Sains Sosio Humaniora LPPM Universitas Jambi, 2(1), 16-24.

Muspawi, M. (2017). Implementasi Supervisi Akademik pada MAN Insan Cendekia Provinsi Jambi. Ta'dib: Jurnal Pendidikan Islam, 6(2), 291-298.

Sugiyono, Prof. "Memahami Penelitian Kualitatif." Bandung: Alfabeta (2005)

Sukarno, M. (2017). Mengembangkan Madrasah Aliyah Negeri Insan Cendikia Untuk Menjawab Tantangan Modernisasi, Demokratisasi dan Globalisasi (Developing Insan Cendikia High School To Address Modernisation, Democracy, And 
Globalisation Challenges). Jurnal Kependudukan Indonesia, 9(2), 117-134.

Syahrul, S. (2017). Perencanaan Strategis dan Praktiknya di Perguruan Tinggi. Shautut Tarbiyah, 23(1), 142-159.

Syahrul, S. (2013). Penelitian sebagai Instrumen Perbaikan Kualitas Kinerja Organisasi Pendidikan secara Berkelanjutan (Continuous Improvement). Al-Ta'dib, 6(1), 150-163. 